\title{
Stratospheric sulfate geoengineering could enhance the terrestrial photosynthesis rate
}

\author{
L. Xia ${ }^{1}$, A. Robock ${ }^{1}$, S. Tilmes ${ }^{2}$, and R. R. Neely III ${ }^{2,3}$ \\ ${ }^{1}$ Department of Environmental Sciences, Rutgers University, New Brunswick, NJ, USA \\ ${ }^{2}$ National Center for Atmospheric Research, Atmospheric Chemistry Division, Boulder, CO, USA \\ ${ }^{3}$ National Centre for Atmospheric Science and the Institute of Climate and Atmospheric Science, University of Leeds, \\ Leeds, UK \\ Correspondence to: L. Xia (lxia@envsci.rutgers.edu)
}

Received: 18 August 2015 - Published in Atmos. Chem. Phys. Discuss.: 21 September 2015

Revised: 20 January 2016 - Accepted: 21 January 2016 - Published: 10 February 2016

\begin{abstract}
Stratospheric sulfate geoengineering could impact the terrestrial carbon cycle by enhancing the carbon sink. With an $8 \mathrm{Tg} \mathrm{yr}^{-1}$ injection of $\mathrm{SO}_{2}$ to produce a stratospheric aerosol cloud to balance anthropogenic radiative forcing from the Representative Concentration Pathway 6.0 (RCP6.0) scenario, we conducted climate model simulations with the Community Earth System Model - the Community Atmospheric Model 4 fully coupled to tropospheric and stratospheric chemistry (CAM4-chem). During the geoengineering period, as compared to RCP6.0, landaveraged downward visible $(300-700 \mathrm{~nm})$ diffuse radiation increased $3.2 \mathrm{~W} \mathrm{~m}^{-2}(11 \%)$. The enhanced diffuse radiation combined with the cooling increased plant photosynthesis by $0.07 \pm 0.02 \mu \mathrm{mol} \mathrm{C} \mathrm{m}^{-2} \mathrm{~s}^{-1}$, which could contribute to an additional $3.8 \pm 1.1 \mathrm{GtC} \mathrm{yr}^{-1}$ global gross primary productivity without explicit nutrient limitation. This increase could potentially increase the land carbon sink. Suppressed plant and soil respiration due to the cooling would reduce natural land carbon emission and therefore further enhance the terrestrial carbon sink during the geoengineering period. This potentially beneficial impact of stratospheric sulfate geoengineering would need to be balanced by a large number of potential risks in any future decisions about the implementation of geoengineering.
\end{abstract}

\section{Introduction}

Stratospheric sulfate injection is one of the most discussed geoengineering strategies for manipulating the climate system to counteract anthropogenic global warming (e.g., Crutzen, 2006; Wigley, 2006). Regularly injected sulfate aerosol precursors could produce aerosols that would stay in the stratosphere for 1-2 years, depending on the particle size and emission rate (Rasch et al., 2008a; Niemeier et al., 2011). This would reduce incoming solar radiation and therefore reduce the temperature (e.g., Rasch et al., 2008a; Robock et al., 2008; Jones et al., 2010; Berdahl et al., 2014). As explained in the initial design of the Geoengineering Model Intercomparison Project (GeoMIP) experiment (Kravitz et al., 2011), reducing the solar constant is another way to simulate sulfate injection geoengineering, and is easier to implement in a climate model. It was used in earlier geoengineering simulations (e.g., Govindasamy and Caldeira, 2000), and also can be thought of as a model of satellites in space blocking sunlight, as proposed by Angel (2006). Although the two methods could both potentially cool the surface, if they could ever be implemented, they would produce different climate responses, including stratospheric ozone depletion, troposphere ozone change, downward ultraviolet radiation, and downward diffuse radiation (e.g., Niemeier et al., 2013; Kalidindi et al., 2015; Nowack et al., 2015). Climate changes due to sunshade geoengineering and sulfate injection geoengineering have been extensively studied (Rasch et al., 2008b, 2009; Robock, 2008), including enhanced stratospheric ozone depletion (Tilmes et al., 2008; 
Heckendorn et al., 2009; Pitari et al., 2014) and possible drought in summer monsoon regions (Robock et al., 2008; Bala et al., 2008; Jones et al., 2013; Tilmes et al., 2013). There are also a couple studies of its impact on the ecosystem - mainly focusing on the net primary productivity (Glienke et al., 2015; Kalidindi et al., 2015), the carbon cycle (Tjiputra et al., 2015), and on agriculture (Pongratz et al., 2012; Xia et al., 2014). However, diffuse radiation perturbations and their biological consequences are only mentioned in a few previous studies (e.g., Robock, 2008; Robock et al., 2009; Glienke et al., 2015), and need to be comprehensively studied.

Volcanic eruptions as a natural analog of sulfate injection geoengineering provide evidence that sulfate aerosols in the stratosphere cool the surface and dramatically change the partitioning of downward direct and diffuse solar radiation (Robock, 2000, 2005). After the Mt. Pinatubo eruption in 1991 there was a sharp slowing of the $\mathrm{CO}_{2}$ atmospheric concentration growth rate. This was mainly due to a strong terrestrial biosphere sink in the middle latitudes of the Northern Hemisphere that balanced the stronger oceanic $\mathrm{CO}_{2}$ outgassing due to a simultaneous El Niño and increasing anthropogenic emission (Keeling et al., 1995; Ciais et al., 1995). Cooling due to volcanic eruptions (Robock, 2000) might be one explanation of the unusual biospheric sink, since the cooling benefits tropical plant growth and reduces the release of $\mathrm{CO}_{2}$ by soil respiration and wildfires (Keeling et al., 1995; Nemani et al., 2003). On the other hand, increased diffuse radiation promotes plant productivity $(\mathrm{Gu}$ et al., 1999, 2002, 2003; Roderick et al., 2001; Cohan et al., 2002; Farquhar and Roderick, 2003; Mercado et al., 2009). In total, in 1992 and 1993, an additional 1.2-1.5 $\mathrm{Gt} \mathrm{C} \mathrm{yr}^{-1}$ was captured by terrestrial vegetation (Mercado et al., 2009). Global dimming (reduction of downward shortwave radiation due to tropospheric pollution after World War II) is another example of how diffuse radiation promotes terrestrial vegetation growth (e.g., Wild, 2009; Mercado et al., 2009). With the geographically varying changes in diffuse radiation fraction $(0$ to $+30 \%)$ due to global dimming (1950-1980), the terrestrial carbon sink increased by $0.4 \mathrm{Gt} \mathrm{C} \mathrm{yr}^{-1}$ (Mercado et al., 2009). A recent study also showed that Amazon fires of 1998-2007 increased the annual mean diffuse radiation by $3.4-6.8 \%$ due to biomass burning aerosols, which would benefit the net primary productivity by $1.4-2.8 \%$ in the Amazonian forests and balance 33-65\% of the annual carbon emissions from biomass burning (Rap et al., 2015). Long-term sulfate injection geoengineering would produce a permanent sulfate aerosol cloud in the stratosphere, and this long-term diffuse radiation enhancement, together with the cooling effect, would likely play an important role in the terrestrial carbon budget.

\section{Model and experiment design}

We used the full tropospheric and stratospheric chemistry version of the Community Earth System Model 1 - Community Atmospheric Model 4 (CESM1 CAM4-chem) with horizontal resolution of $0.9^{\circ} \times 1.25^{\circ}$ lat-long and 26 levels from the surface to about $40 \mathrm{~km}(3.5 \mathrm{mb})$ (Lamarque et al., 2012; Tilmes et al., 2015a, 2016) to simulate two solar radiation management schemes: a specific sulfate injection scenario and a solar constant reduction scenario. Since the experiments are branched from the Climate Chemistry Model Initiative (CCMI) runs in which CAM4-chem participates, we used the same configuration as the reference run. Therefore we used the Community Land Model (CLM) version 4.0 with prescribed satellite phenology (CLM4SP) instead of the version of CLM with a carbon-nitrogen cycle, coupled with CAM4-chem. This model calculates vegetation photosynthesis under the assumption of prescribed phenology and no explicit nutrient limitations (Bonan et al., 2011). With the satellite phenology option, although nitrogen limitation is not explicitly included, there is some inherent nitrogen limitation because nitrogen availability limits the leaf area index in the satellite measurements used in CLM4SP, and the model has been validated with gross primary productivity (GPP) observations. Dynamic vegetation is not turned on in this study. The ocean model does not include any biogeochemical calculations in this study.

The specific sulfate injection scenario is G4 Specified Stratospheric Aerosol (G4SSA), which uses a prescribed stratospheric aerosol distribution to simulate a continuous annual tropical emission into the stratosphere (at $60 \mathrm{mb}$ ) of $8 \mathrm{Tg} \mathrm{SO}_{2} \mathrm{yr}^{-1}$ from 2020 to 2070 , which produces a radiative forcing of about $-2.5 \mathrm{~W} \mathrm{~m}^{-2}$. The steady-state aerosol surface area density has the highest value of $33.2 \mu \mathrm{m}^{2} \mathrm{~cm}^{-3}$ in the tropics at $50-60 \mathrm{mb}$ and gradually decreases to $10-$ $12 \mu \mathrm{m}^{2} \mathrm{~cm}^{-3}$ at the poles (Tilmes et al., 2015b). Starting on 1 January, 2070, the sulfate injection reduces gradually to zero on 31 December, 2071 (Tilmes et al., 2015b). The G4SSA simulation continues after the end of sulfate injection from 2072 to 2089 in order to study the termination effect. Using specified stratospheric aerosols, tropospheric aerosols are not changed, and therefore we cannot evaluate how the geoengineered stratospheric sulfate aerosols would be transported into the troposphere and affect tropospheric chemistry. Using a fixed stratospheric aerosol distribution to compare the effect of geoengineered stratospheric aerosols in different models is similar to what has been done to investigate the impact of volcanic eruptions in chemistry climate model comparison projects in the past. For more details on the prescription of stratospheric aerosols in CAM4-chem, see Neely III et al. (2015). The reference simulation is the Representative Concentration Pathway 6.0 (RCP6.0) (Meinshausen et al., 2011) from 2004 to 2089. We have run three ensemble members for both G4SSA and RCP6.0. 
The solar constant reduction scenario is the G3 solar constant reduction (G3S) which reduces the solar constant to balance the forcing of the Representative Concentration Pathway 4.5 (RCP4.5) (Meinshausen et al., 2011) and keeps the temperature close to 2020 values. This solar reduction geoengineering scenario is from 2020 to 2069, and its reference run is RCP4.5 from 2004 to 2089 . The reason we used different reference runs (RCP4.5 and RCP6.0) for the two experiments (G3S and G4SSA) is that they come from different phases of GeoMIP. G3S was initiated before G4SSA at the start of GeoMIP and the reference run for the first phase of GeoMIP was RCP4.5. G4SSA participates in both GeoMIP and CCMI. Since RCP6.0 is the standard reference run for CCMI, to encourage more climate chemistry modeling groups to participate in G4SSA and generate robust understanding of how atmospheric chemistry responds to sulfate injection geoengineering, Tilmes et al. (2015b) proposed that G4SSA be based on RCP6.0. Since the anthropogenic forcing is very similar for RCP4.5 and RCP6.0 between 2020 and 2070, we expect very little difference between the two experiments. The basic principle that solar dimming does not affect stratospheric ozone or produce diffuse radiation, in the way that stratospheric aerosols do, is well illustrated by the $\mathrm{G} 3 \mathrm{~S}$ results. Both $\mathrm{G} 3 \mathrm{~S}$ and RCP4.5 have only one ensemble member each.

\section{Results}

\subsection{Climate and radiation response}

Under the RCP6.0 scenario, the anthropogenic greenhouse gas radiative forcing increases global average surface air temperature from 288.5 to $290.2 \mathrm{~K}$ during the period of 2004-2089 (Fig. 1a). The higher temperature enhances the hydrological cycle, and therefore global precipitation as well as land average evaporation (Fig. 1b, g) increase. Global soil water content (top $10 \mathrm{~cm}$, including liquid water and ice) slightly increases with global warming (Fig. 1i). The global surface downward solar radiation gradually decreases by about $1 \mathrm{~W} \mathrm{~m}^{-2}$ during the period 2004-2089 (Fig. 1d) as the total cloud coverage increases, particularly low-cloud coverage, which increases by $0.7 \%$ (Fig. 1c). However, the landaverage visible direct solar radiation shows an upward trend (Fig. 1e) due to the effects of gradual tropospheric aerosol reductions under RCP6.0. The downward total solar radiation averaged over land (not shown) also has a slight increasing trend from 2004 to 2089, which is opposite to the globally averaged surface solar radiation trend. There are two reasons for this: the reduction in aerosol emissions mainly affects the continents and the increase of cloud coverage is mainly over the ocean. Averaged visible diffuse radiation $(300-700 \mathrm{~nm})$ over land decreases in RCP6.0 (Fig. 1f) due to the decrease of aerosol emission in the RCP6.0 scenario (Meinshausen et al., 2011). Under this global warming scenario, vegetated- land-averaged canopy transpiration decreases mainly due to increasing $\mathrm{CO}_{2}$ (Fig. 1h) (Reddy et al., 1995).

With $1.6 \mathrm{~W} \mathrm{~m}^{-2}$ less total surface solar radiation (Fig. 1d), G4SSA successfully cools the surface by $0.8 \pm 0.2 \mathrm{~K}$ as compared to RCP6.0 (Fig. 1a). This cooling slows down the hydrology cycle with less average precipitation $\left(-0.07 \mathrm{~mm} \mathrm{day}^{-1},-2.5 \%\right)$ (Fig. 1b), less ground evaporation (Fig. 1g), and less global low-cloud coverage (Fig. 1c), which is consistent with previous studies (e.g., Niemeier et al., 2013; Tilmes et al., 2013; Jones et al., 2013; Kalidindi et al., 2015). Furthermore, there is no change in the soil water content under G4SSA and RCP6.0 scenarios (Fig. 1i). Visible diffuse radiation over the land increases significantly (Fig. 1f) as the sulfate aerosols in the stratosphere $(3.0 \mathrm{Tg} \mathrm{S}$ equilibrium loading; Tilmes et al., 2015b) scatter solar radiation. Therefore, while the total surface solar radiation reduces by $1.6 \mathrm{~W} \mathrm{~m}^{-2}$, the visible diffuse solar radiation increases by $3.2 \mathrm{~W} \mathrm{~m}^{-2}$ over land under all sky conditions. Kalidindi et al. (2015) showed that with a $20 \mathrm{Tg}$ sulfate aerosol $\left(\mathrm{SO}_{4}\right)$ stratospheric loading to balance the radiative forcing of $2 \times \mathrm{CO}_{2}$, broadband diffuse radiation would increase by $11.2 \mathrm{~W} \mathrm{~m}^{-2}$ compared with the reference run. However they used a very unrealistic stratospheric aerosol distribution, with a very small effective radius of $0.17 \mu \mathrm{m}$ and uniform geographical distribution. In fact, 3 months after the eruption of Mt. Pinatubo in 1991, broadband diffuse radiation increased from 40 to $140 \mathrm{~W} \mathrm{~m}^{-2}$ under clear-sky conditions at the Mauna Loa observatory (Robock, 2005), but only the edge of the Pinatubo cloud was over Mauna Loa, and the maximum effect was even greater. The photosynthesis rate of a northern hardwood forest (Harvard Forest) increased $23 \%$ in 1992 compared with an unperturbed year (1997) (Gu et al., 2003). Therefore, under this sulfate injection geoengineering scenario, which is equivalent to one 1991 Pinatubo eruption every 2.5 years (Bluth et al., 1992) with the assumption that all sulfate aerosol will reach the stratosphere, diffuse radiation enhancement is expected to enhance the terrestrial photosynthesis rate and potentially increase the land carbon sink. Furthermore, the drier, cooler, and more diffuse radiation environment under G4SSA reduces the canopy transpiration comparing with RCP6.0 (Fig. 1h) (Kanniah et al., 2012), which may indicate that less $\mathrm{CO}_{2}$ is released back to the atmosphere by plant respiration.

Solar constant reduction climate intervention (G3S) efficiently cools the surface as well. Since there is less radiative forcing reduction due to the experiment design, the annual global-averaged temperature reduction (gradually from 0 to $0.8^{\circ} \mathrm{C}$ ) is less than the reduction in G4SSA. Precipitation and ground evaporation also reduce under G3S. However, G3S has no effect on diffuse radiation compared with RCP4.5, since there are no additional aerosols injected into the atmosphere. The overall trend of surface visible diffuse radiation in both G3S and RCP4.5 slowly decreases because of decreasing emissions (the tropospheric aerosol removal effect in RCP4.5, not shown). Although the two experiments 

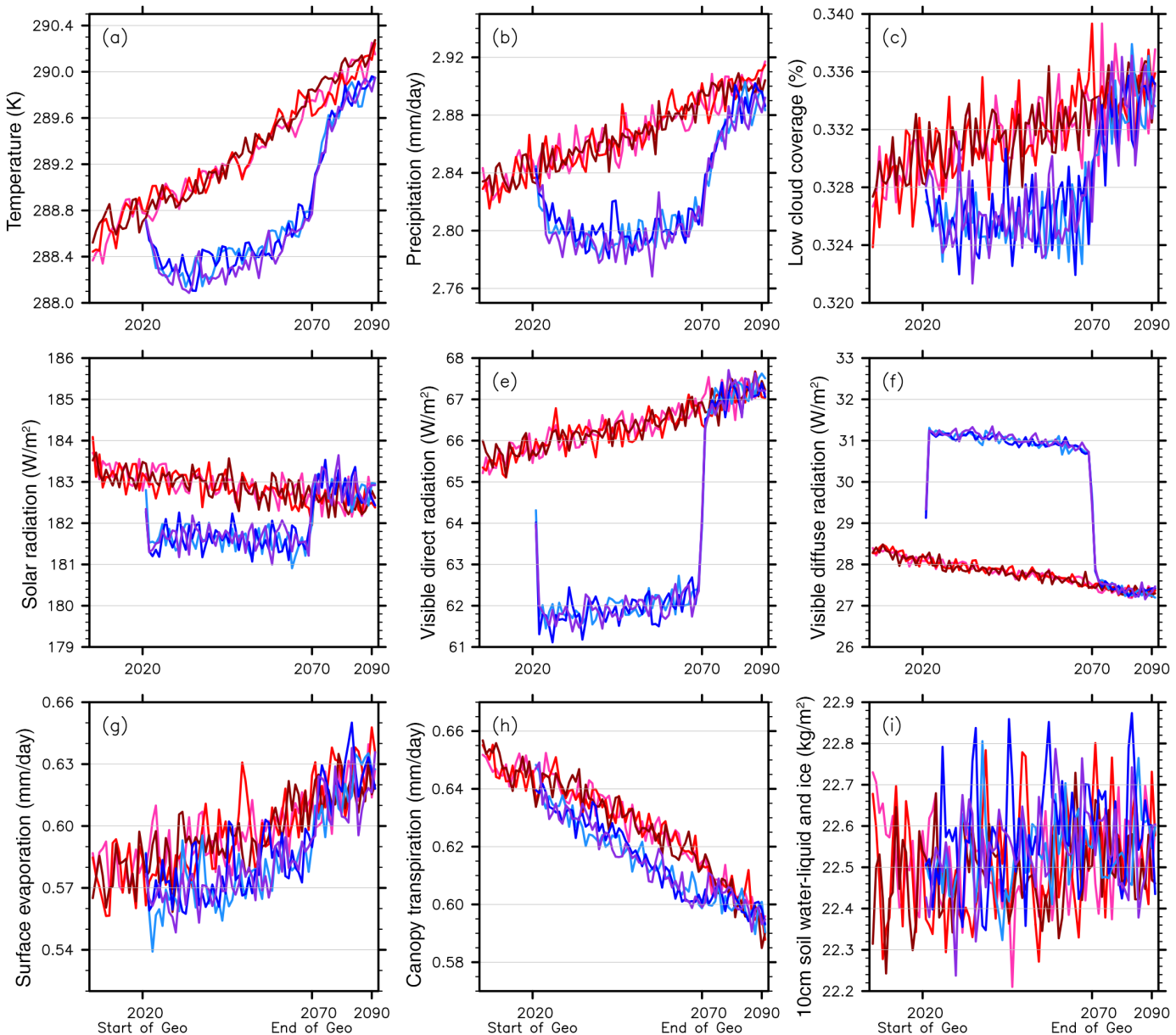

Figure 1. Global-average (a) temperature, (b) precipitation, (c) low cloud coverage, and (d) surface downward solar radiation under G4SSA sulfate injection geoengineering (blue lines) and under RCP6.0 (red lines). Land-average (e) surface downward visible direct radiation, (f) diffuse radiation, (g) surface evaporation, (h) canopy transpiration, and (i) vegetated land top $10 \mathrm{~cm}$ soil water (liquid water and ice) content under G4SSA (blue lines) and RCP 6.0 (red lines). The three red lines and blue lines indicate three ensemble members of RCP6.0 and G4SSA. Sulfate injection starts at 2020 and ends at 2070.

have different radiative forcing reductions: $2.5 \mathrm{~W} \mathrm{~m}^{-2}$ for G4SSA and $0-1.5 \mathrm{~W} \mathrm{~m}^{-2}$ for G3S, we expect linear changes in temperature and precipitation corresponding to the radiative forcing change (Irvine et al., 2010; Kravitz et al., 2014). We focus on the diffuse radiation effect in this study, which is included in G4SSA and excluded in G3S due to the experiment design. Therefore, it is reasonable to compare the two experiments with regard to their diffuse radiation effect on photosynthesis.

\subsection{Diffuse radiation and climate change impacts on vegetation photosynthesis rate}

Diffuse radiation is more advantageous for plant productivity than direct radiation (e.g., Gu et al., 2002) because diffuse radiation provides more homogeneous distribution of radiation within the canopy and more light can be absorbed by shaded leaves without exceeding the photosynthetic capac- ity of the plants. Increased diffuse radiation within a certain range will promote plant net production productivity and therefore enhance the carbon sink (Niyogi et al., 2004; Misson et al., 2005; Oliveira et al., 2007). However, if the aerosol load exceeds a certain level it will suppress photosynthesis (Chameides et al., 1999; Cohan et al., 2002). Knohl and Baldocchi (2008) and Mercado et al. (2009) estimated that the tipping point of the diffuse radiation effect is a ratio of 0.40 0.45 between diffuse radiation and total solar radiation; this is the maximum ratio with a positive effect on plant photosynthesis. Under our sulfate injection climate intervention scenario, the ratio of diffuse radiation and total solar radiation increases from 0.296 to 0.333 . Therefore, the increase of diffuse radiation in our study would have a positive impact on plant photosynthesis.

Without explicit nutrient limitation, simulated land average photosynthesis would continuously increase in the fu- 

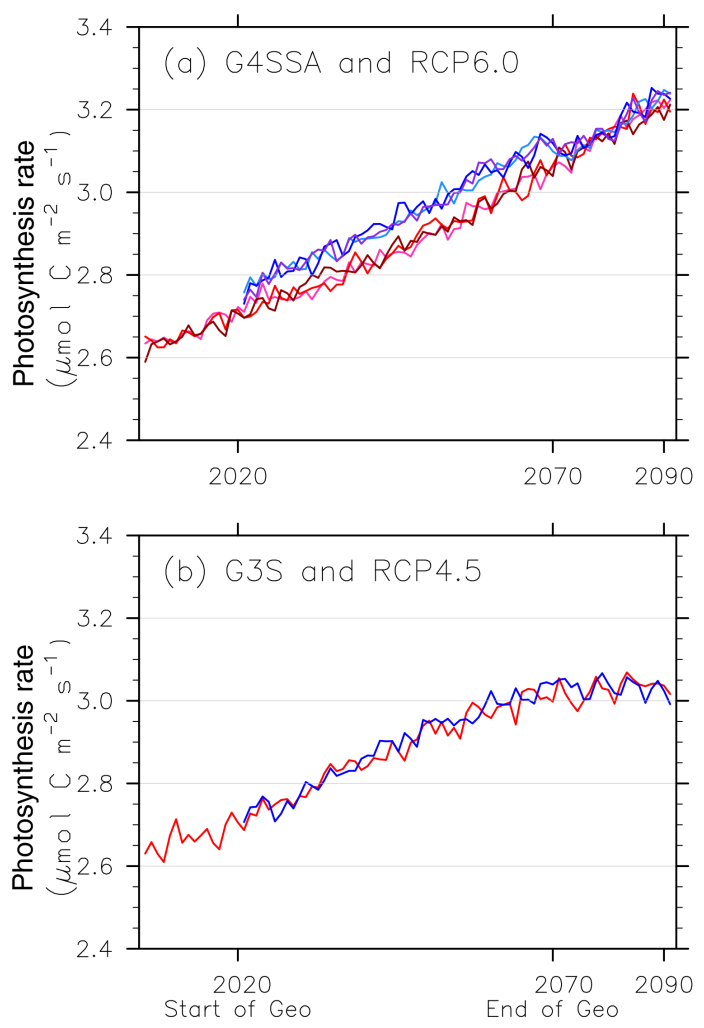

Figure 2. Land average photosynthesis rate without explicit nutrient limitation (a) under sulfate injection geoengineering (G4SSA) (blue lines) and RCP6.0 (red lines) and (b) under solar constant reduction geoengineering (G3S) (blue line) and RCP4.5 (red line).

ture due to the stronger $\mathrm{CO}_{2}$ fertilization effect as the $\mathrm{CO}_{2}$ concentration increases from $377 \mathrm{ppm}$ (2004) to $632 \mathrm{ppm}$ (2089) (Fig. 2a) (e.g., Allen et al., 1987; Leakey et al., 2009). However, this model-simulated increase may not be realistic, since the actual photosynthesis rate is limited by the amount of soil nutrients such as nitrogen and phosphorus (e.g., Vitousek and Howarth, 1991; Davidson et al., 2004; Elser et al., 2007). Under the G4SSA scenario, global-averaged photosynthesis increases to $0.07 \pm 0.02 \mu \mathrm{mol} \mathrm{C} \mathrm{m}{ }^{-2} \mathrm{~s}^{-1}$ compared with that in the RCP6.0 scenario (Fig. 2a). This enhancement is due to the combination of the climate changes, such as cooling, and diffuse radiation enhancement. Different types of plants show maximum photosynthesis rates at certain optimal temperatures, depending on $\mathrm{CO}_{2}$ concentrations (e.g., Sage and Kubien, 2007). Figure 3 shows that the photosynthesis rate in different regions responds to G4SSA differently and temperature plays an important role. In general, the cooling effect from solar radiation management would increase photosynthesis in tropical regions where there is likely to be extreme heat stress under the global warming scenario, and slow down photosynthesis in high latitude regions, since the temperature has not exceeded the optimal temperature even under the global warming scenario. In the tropics, the photosynthesis rate change has an increasing trend (Fig. 3),

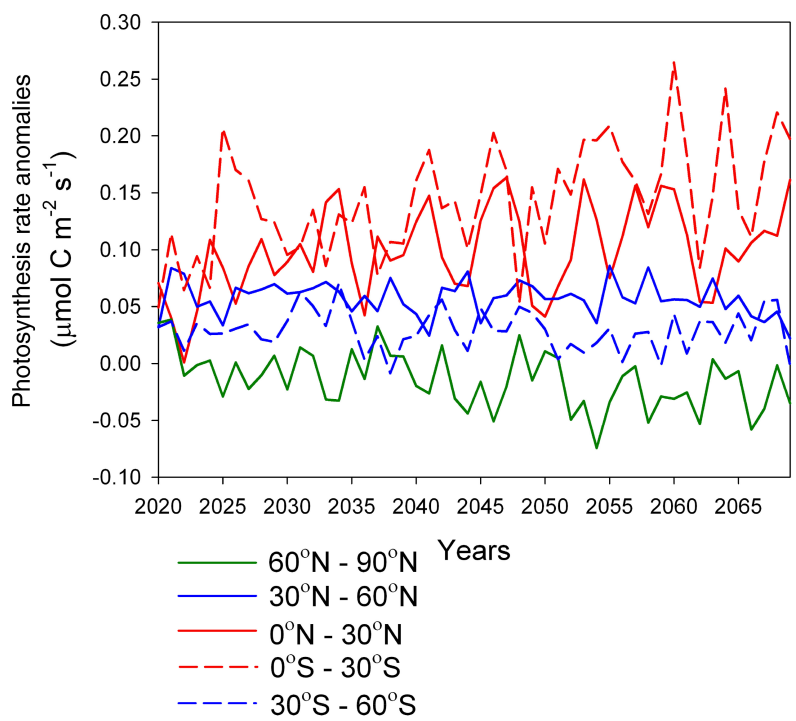

Figure 3. Regional-averaged annual photosynthesis rate difference of G4SSA minus RCP6.0 from 2020 to 2069 when sulfate injection geoengineering was applied.

because the cooling effect of G4SSA benefits photosynthesis more when global warming gets severe. Furthermore, the large variation of the photosynthesis rate change in the tropics (Fig. 3) might be related to the strong sensitivity of tropical forest to precipitation change (Phillips et al., 2009; Tjiputra et al., 2015).

Figure $2 \mathrm{~b}$ shows the photosynthesis rates in G3S and RCP4.5. Without the diffuse radiation effect, the landaveraged photosynthesis rate has no significant change under solar radiation management (G3S). The cooling effect on photosynthesis has been canceled out by combining increases in tropical regions and decreases in temperate regions (Fig. 4b). Therefore, the increase of the photosynthesis rate in Fig. 2a under the G4SSA scenario is primarily caused by the enhancement of diffuse radiation.

Without explicit nutrient limitation, the increase of the photosynthesis rate is almost entirely over vegetated land during years 2030-2069 of G4SSA compared with RCP6.0 (Fig. 4a) as a combination impact of climate factors controlling plant photosynthesis (Fig. 5). The strongest increase is in the Amazon rainforest with a value of $1.42 \mu \mathrm{mol} \mathrm{C} \mathrm{m}^{-2} \mathrm{~s}^{-1}$ (26.3\%) (Fig. 4a), where multiple layers of the canopy, especially the tallest canopy, would receive more diffuse radiation, and the cooling helps plant growth during the entire year. Those two positive impacts of diffuse radiation and surface temperature changes from G4SSA are countered by the negative impacts from the regional reductions of soil water content (not shown here) and the global reduction of total solar radiation (Fig. 5b and c). In a previous study, precipitation was found to be the largest climate factor controlling GPP during 1998-2005 (Beer et al., 2010). Considering that the global forest carbon sink was $2.41 \pm 0.42 \mathrm{GtC} \mathrm{yr}^{-1}$ dur- 
ing the period of 1990-2007, and the Amazon rainforest contributes $\sim 25 \%$ (Pan et al., 2011), increasing its photosynthesis rate by $4.2 \pm 5.9 \%$ would potentially help to bring more carbon out of the atmosphere. Since, in reality, most Amazonian soils are highly weathered and relatively nutrient poor, this simulated increase might be overestimated (Davidson et al., 2004). However, in our study, the prescribed plant phenology has some inherent nutrient limitation, and therefore the overestimation should not be substantial. In high latitude and high altitude regions, although increasing diffuse radiation still increases the photosynthesis rate, temperature reduction has a negative impact on photosynthesis (Fig. 5a), which is consistent with a previous study (Glienke et al., 2015), and the stronger temperature reduction in high latitude regions would reduce the photosynthesis rate (Fig. 4a). Over high altitude regions, such as the Rocky Mountains and the Himalayas, increased snow cover (not shown here) contributes to the reduction of photosynthesis under G4SSA as well. The expected reduction in the stratospheric ozone column in high latitudes, due to increased heterogeneous reactions promoting ozone-destroying cycles, increases UV radiation (e.g., Pitari et al., 2014), which will not be further investigated in this study. Furthermore, changes in tropospheric chemistry and stratosphere-troposphere exchange due to G4SSA could modify the surface ozone concentration regionally, which may be another potential impact on the photosynthesis rate. Further investigation of those issues is needed.

Without the diffuse radiation effect, the photosynthesis rate differences between G3S and RCP4.5 are not significant in more regions (Fig. 4b) than for the differences between G4SSA and RCP6.0. The Amazon rainforest still has the largest photosynthesis increase, with a maximum value of $1.24 \mu \mathrm{mol} \mathrm{C} \mathrm{m} \mathrm{C} \mathrm{s}^{-1}$, but the average photosynthesis change in the Amazon region is only $0.7 \pm 5.7 \%$. The two climate interventions (G4SSA and G3S) have different assumptions and different reference runs (RCP6.0 and RCP4.5) and they have different levels of cooling, different precipitation changes, and different $\mathrm{CO}_{2}$ concentrations. We cannot, therefore, evaluate how much the enhancement of diffuse radiation contributes to the increase of photosynthesis. When comparing the global-averaged photosynthesis change (Fig. 2) with the cooling effect, the diffuse radiation change does increase the carbon uptake significantly with a $p$ value less than 0.002 .

\subsection{Diffuse radiation and climate change impacts on the terrestrial carbon sink}

We have calculated the additional carbon sink due to the increase of photosynthesis. Using the land area $\left(1.5 \times 10^{8} \mathrm{~km}^{2}\right)$ in CLM, for G4SSA, the global land average photosynthesis rate increases $0.07 \pm 0.02 \mu \mathrm{mol} \mathrm{C} \mathrm{m}^{-2} \mathrm{~s}^{-1}$ compared with RCP6.0. Therefore, the increase of the photosynthesis rate without explicit nutrient limitation would in-

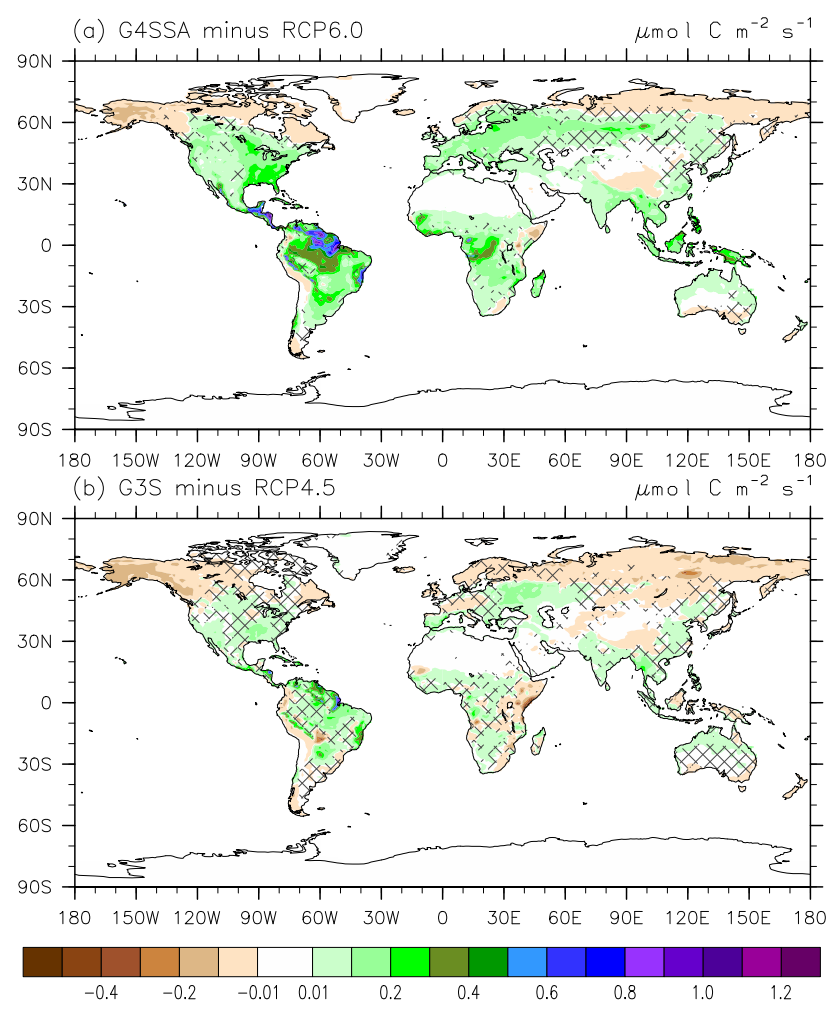

Figure 4. (a) Photosynthesis rate differences between G4SSA and RCP6.0 during years 2030-2069 (sulfate injection period, excluding the first 10 years). (b) Photosynthesis rate anomaly between G3S and RCP4.5 during years 2030-2069 of solar reduction. Hatched regions are areas with $p>0.05$ (where changes are not statistically significant based on a paired $t$ test).

crease GPP by $3.8 \pm 1.1 \mathrm{GtC} \mathrm{yr}^{-1}$ from terrestrial vegetation. Mercado et al. (2009) estimated that after the 1991 eruption of Mt. Pinatubo the land carbon sink increased by 1.13 in 1992 and $1.53 \mathrm{Gt} \mathrm{C} \mathrm{yr}^{-1}$ in 1993, which was the result of both diffuse radiation and the cooling effect. The diffuse radiation effect was the dominant factor in $1992\left(1.18 \mathrm{Gt} \mathrm{C} \mathrm{yr}^{-1}\right)$, while it was much less significant in $1993\left(0.04 \mathrm{Gt} \mathrm{C} \mathrm{yr}^{-1}\right)$.

\section{Discussion}

Our result of increasing of gross primary productivity due to enhanced stratospheric aerosols has uncertainties and needs to be further evaluated with new experiments using multiple Earth system models. Since the carbon-nitrogen cycle in CLM4 is turned off, leaf area index (LAI) cannot be diagnosed by the climate changes due to G4SSA and hence the photosynthesis response may be biased. However, even if we use CLM4CN with the carbon-nitrogen cycle modeled, the photosynthesis response would still be imperfectly modeled, since there is a high bias in the LAI simulation and structural errors in the leaf photosynthesis process (Lawrence et al., 2012). Also, without dynamic vegetation, our study keeps 

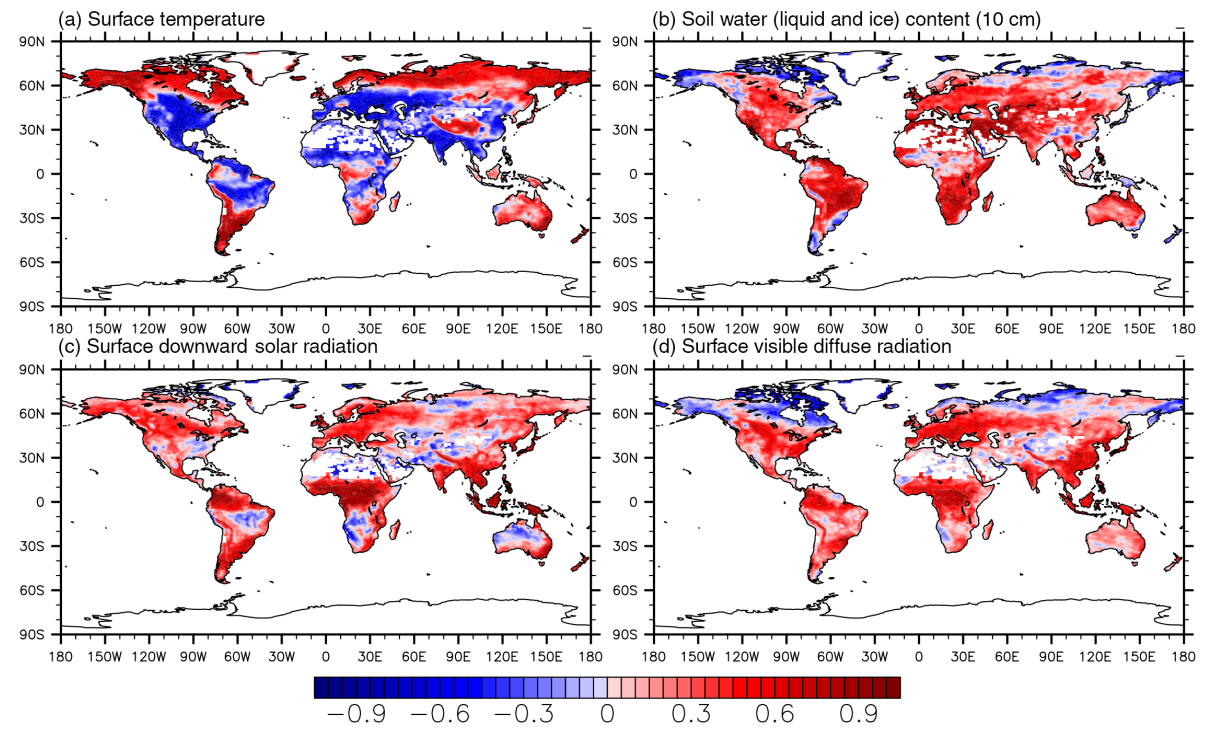

Figure 5. Correlation coefficient of the monthly photosynthesis rate anomalies in JJA during years 2030-2069 (G4SSA minus RCP6.0, Fig. 3a) and (a) surface temperature anomalies, (b) top $10 \mathrm{~cm}$ soil water (including liquid water and ice) anomalies, (c) surface downward solar radiation anomalies, and (d) surface visible diffuse radiation anomalies during years 2030-2069.

a prescribed plant functional type during the whole simulation, and cannot simulate plant type change under a different climate.

Another source of uncertainty is the use of only one climate model. Jones et al. (2013) and Glienke et al. (2015) showed that there is a large range of simulated net primary productivity (NPP) changes as the $\mathrm{CO}_{2}$ concentration increases or under solar reduction geoengineering using different land models, which is mainly due to the availability of a nitrogen cycle. With a nitrogen cycle, there is a much smaller $\mathrm{CO}_{2}$ fertilization effect on plant growth. We expect that with the carbon-nitrogen cycle turned on, the upward trend of the photosynthesis rate under both G4SSA and RCP6.0 in Fig. 2a will be reduced. Furthermore, models respond to different climates at the same atmospheric $\mathrm{CO}_{2}$ concentration differently. Eight models participating in the GeoMIP G1 (instantaneously quadrupling of the $\mathrm{CO}_{2}$ concentration (abrupt $4 \mathrm{xCO} 2$ ) while simultaneously reducing the solar constant to balance the forcing) (Kravitz et al., 2011) showed different and even opposite trends of NPP changes between abrupt $4 \times \mathrm{CO} 2$ and $\mathrm{G} 1$ because of different behaviors in GPP and respiration (Glienke et al., 2015). In G1, GPP as well as NPP reduced compared with abrupt $4 \mathrm{xCO} 2$ using CCSM4 (CAM4 coupled with CLM4CN). However, G1 has a much stronger temperature reduction and no diffuse radiation change. Considering the inconsistent responses of models to geoengineering-induced climate changes even with the same $\mathrm{CO}_{2}$ concentration, multiple model study is necessary to better understand how photosynthesis and NPP would change under sulfate injection geoengineering.

Sulfate injection geoengineering could potentially change the terrestrial carbon sink since it might increase GPP com- pared with a global warming scenario due to the diffuse radiation and other climate changes. However, to further investigate this issue, we need to consider other mechanisms that sulfate injection geoengineering would trigger. The cooling effect would also suppress plant and soil respiration. After the eruption of Mt. Pinatubo, the terrestrial carbon sink increased due to both the cooling effect (Ciais et al., 1995; Keeling et al., 1995) and the diffuse radiation fertilization effect (Jones and Cox, 2001; Lucht et al., 2002). Mercado et al. (2009) estimated that the cooling effect and diffuse radiation equally contributed to the enhancement of the terrestrial net primary productivity changes in 1992 , since the cooling effect suppresses soil respiration and reduces carbon emissions. In 1993, the cooling effect actually enhances the land carbon sink more than the diffuse radiation. Since heterotrophic respiration (the decomposition of soil organic carbon) might be more sensitive to temperature change than GPP (Jenkinson et al., 1991) that would further enhance the terrestrial carbon sink due to cooling from sulfate injection geoengineering. Therefore, if we include the reduction of plant and soil respiration due to the cooling effect, land processes would capture even more carbon in sulfate injection geoengineering scenarios. However, current land models tend to simulate soil organic carbon decomposition under climate changes in a simple way, which might not be able to accurately predict the temperature sensitivity of global soil organic carbon decomposition as well as the terrestrial carbon cycle change under future climate changes (Davidson and Janssens, 2006).

In our simulations, the $\mathrm{CO}_{2}$ concentration is prescribed in both G4SSA and RCP6.0, but we expect that the $\mathrm{CO}_{2}$ concentration of G4SSA might be lower than the global warm- 
ing scenario due to the diffuse radiation and the cooling effects, since this $\mathrm{CO}_{2}$ concentration change has been observed after volcanic eruptions due to enhanced land carbon sinks (Keeling et al., 1995; Ciais et al., 1995). The predicted $\mathrm{CO}_{2}$ concentration increase rate based on industrial emissions in the early 1990 s was $1.7 \% \mathrm{yr}^{-1}$, but the observed $\mathrm{CO}_{2}$ concentration after 1991 declined instead of increasing. However, the atmospheric $\mathrm{CO}_{2}$ concentration is also highly impacted by another carbon reservoir, the ocean. The ocean covers most of Earth, and $\mathrm{CO}_{2}$ feedbacks from geoengineering will also occur in the ocean, including responses dependent on the ocean surface temperature, ocean biological processes, and changing ocean dynamics (Tjiputra et al., 2015). For example, an El Niño will cause the ocean to temporarily emit more $\mathrm{CO}_{2}$ to the atmosphere. Although idealized geoengineering experiments have not shown any significant effect on El Niño (Gabriel and Robock, 2015), a longer period of geoengineering might impact ocean circulation. The ocean model we used simulates dynamical and temperature responses, but does not include a biochemical and carbon cycle. Such responses will need to be included for an integrated assessment of the impacts of geoengineering on the global carbon budget.

Although there have been many reasons to be hesitant about the implementation of geoengineering (Robock, 2012, 2014), sulfate injection climate intervention may have a great potential to increase land GPP, reduce the terrestrial carbon source, and change the ocean carbon cycle. More studies are needed to further understand the details of each process.

\section{Conclusions}

With our experimental design, simulated stratospheric sulfate geoengineering with $8 \mathrm{Tg} \mathrm{yr}^{-1}$ injection of $\mathrm{SO}_{2}$ would change the partitioning of solar radiation with an increase of surface diffuse radiation of about $3.2 \mathrm{~W} \mathrm{~m}^{-2}$ in visible wavelengths over land. This enhanced diffuse radiation combining with other climate changes, such as cooling, soil water content change, and total solar radiation reduction, increased plant photosynthesis rates significantly in temperate and tropical regions, and reduced the photosynthesis rate in high latitude and mountain regions. Overall, the increase of the land-averaged photosynthesis rate is $0.07 \pm 0.02 \mu \mathrm{mol} \mathrm{C} \mathrm{m}{ }^{-2} \mathrm{~s}^{-1}$, which could contribute to an additional $3.8 \pm 1.1 \mathrm{GtC} \mathrm{yr}^{-1}$ global carbon sink. These results are affected by the experimental design, since the carbon-nitrogen cycle and dynamic vegetation are not included. Further investigation is needed to fully understand the contribution of enhanced diffuse radiation due to sulfate geoengineering on the terrestrial carbon sink.

Acknowledgements. This work is supported by U.S. National Science Foundation (NSF) grants AGS-1157525 and GEO-1240507. Computer simulations were conducted on the National Center for Atmospheric Research (NCAR) Yellowstone supercomputer. NCAR is funded by the NSF. The CESM project is supported by the NSF and the Office of Science (BER) of the US Department of Energy. We thank Jean-Francois Lamarque, Daniel Marsh, Andrew Conley, Louisa K. Emmons, Rolando R. Garcia, Anne K. Smith, and Douglas E. Kinnison for the CAM4-chem development. We thank Peter Lawrence and Danica Lombardozzi for helping us understanding how CLM4 calculates photosynthesis. R. R. Neely III was supported by NSF via NCAR's Advanced Study Program. We thank the reviewers, who helped to substantially improve this work.

Edited by: B. Kravitz

\section{References}

Allen Jr., L. H., Boote, K. J., Jones, J. W., Jones, P. H., Valle, R. R., Acock, B., Rogers, H. H., and Dahlman, R. C.: Response of vegetation to rising carbon dioxide: Photosynthesis, biomass, and seed yield of soybean, Global Biogeochem. Cy., 1, 1-14, doi:10.1029/GB001i001p00001, 1987.

Angel, R.: Feasibility of cooling the Earth with a cloud of small spacecraft near the inner Lagrange point (L1), P. Natl. Acad. Sci. USA, 103, 17184-17189, doi:10.1073/pnas.0608163103, 2006.

Bala, G., Duffy, P. B., and Taylor, K. E.: Impact of geoengineering schemes on the global hydrological cycle, P. Natl. Acad. Sci., 105, 7664-7669, doi:10.1073/pnas.0711648105, 2008.

Beer, C., Reichstein, M., Tomelleri, E., Ciais, P., Jung, M., Carvalhais, N., Rödenbeck, C., Arain, M., A., Baldocchi, D., Bonan, G. B., Bondeau, A., Cescatti, A., Lasslop, G., Lindroth, A., Lomas, M., Luyssaert, S., Margolis, H., Oleson, K. W., Roupsard, O., Veenendaal, E., Viovy, N., Williams, C., Woodward, F. I., and Papale, D.: Terrestrial gross carbon dioxide uptake: Global distribution and covariation with climate, Science, 329, 834-838, doi:10.1126/science.1184984, 2010.

Berdahl, M., Robock, A., Ji, D., Moore, J. C., Jones, A., Kravitz, B., and Watanabe, S.: Arctic cryosphere response in the Geoengineering Model Intercomparison Project (GeoMIP) G3 and G4 scenarios, J. Geophys. Res.-Atmos., 119, 1308-1321, doi:10.1002/2013JD020627, 2014.

Bluth, G. J. S., Doiron, S. D., Schnetzler, C. C., Krueger, A. J., and Walter, L. S.: Global tracking of the $\mathrm{SO}_{2}$ clouds from the June, 1991 Mount Pinatubo eruptions, Geophys. Res. Lett., 19, 151154, doi:10.1029/91GL02792, 1992.

Bonan, G. B., Lawrence, P. J., Oleson, K. W., Levis, S., Jung, M., Reichstein, M., Lawrence, D. M., and Swenson, S. C.: Improving canopy processes in the Community Land Model version 4 (CLM4) using global flux fields empirically inferred from FLUXNET data, J. Geophys. Res., 116, G02014, doi:10.1029/2010JG001593, 2011.

Chameides, W. L., Yu, H., Liu, S. C., Bergin, M., Zhou, X., Mearns, L., Wang, G., and Kiang, C. S.: Case study of the effects of atmospheric aerosols and regional haze on agriculture: An opportunity to enhance crop yields in China through emission controls?, P. Natl. Acad. Sci., 96, 13626-13633, doi:10.1073/pnas.96.24.13626, 1999.

Ciais, P., Tans, P. P., Trolier, M., White, J. W. C., and Francey, R. J.: A large Northern Hemisphere terrestrial $\mathrm{CO}_{2}$ sink indicated 
by the $13 \mathrm{C} / 12 \mathrm{C}$ ratio of atmospheric $\mathrm{CO}_{2}$, Science, 269 , 10981102, doi:10.1126/science.269.5227.1098, 1995.

Cohan, D. S., Xu, J., Greenwald, R., Bergin, M. H., and Chameides, W. L.: Impact of atmospheric aerosol light scattering and absorption on terrestrial net primary productivity, Global Biogeochem. Cy., 16, 1090, doi:10.1029/2001GB001441, 2002.

Crutzen, P.: Albedo enhancement by stratospheric sulfur injections: A contribution to resolve a policy dilemma?, Climatic Change, 77, 211-220, doi:10.1007/s10584-006-9101-y, 2006.

Davidson, E. A. and Janssens, I. A.: Temperature sensitivity of soil carbon decomposition and feedbacks to climate change, Nature, 440, 165-173, doi:10.1038/nature04514, 2006.

Davidson, E. A., Reis de Carvalho, C. J., Vieira, I. C. G., Figueiredo, R. d. O., Moutinho, P., Yoko Ishida, F., Primo dos Santos, M. T., Benito Guerrero, J., Kalif, K., and Tuma Sabá, R.: Nitrogen and phosphorus limitation of biomass growth in a tropical secondary forest, Ecol. Appl., 14, 150-163, doi:10.1890/01-6006, 2004.

Elser, J. J., Bracken, M. E. S., Cleland, E. E., Gruner, D. S., Harpole, W. S., Hillebrand, H., Ngai, J. T., Seabloom, E. W., Shurin, J. B., and Smith, J. E.: Global analysis of nitrogen and phosphorus limitation of primary producers in freshwater, marine and terrestrial ecosystems, Ecol. Lett., 10, 1135-1142, doi:10.1111/j.14610248.2007.01113.x, 2007.

Farquhar, G. D. and Roderick, M. L.: Pinatubo, diffuse light, and the carbon cycle, Science, 299, 1997-1998, doi:10.1126/science.1080681, 2003.

Gabriel, C. J. and Robock, A.: Stratospheric geoengineering impacts on El Niño/Southern Oscillation, Atmos. Chem. Phys., 15, 11949-11966, doi:10.5194/acp-15-11949-2015, 2015.

Glienke, S., Irvine, P. J., and Lawrence, M. G.: The impact of geoengineering on vegetation in experiment G1 of the GeoMIP, J. Geophys. Res.-Atmos., 120, 10196-10213, doi:10.1002/2015JD024202, 2015.

Govindasamy, B. and Caldeira, K.: Geoengineering Earth's radiation balance to mitigate $\mathrm{CO}_{2}$-induced climate change, Geophys. Res. Lett., 27, 2141-2144, doi:10.1029/1999GL006086, 2000.

Gu, L., Fuentes, J. D., Shugart, H. H., Staebler, R. M., and Black, T. A.: Responses of net ecosystem exchanges of carbon dioxide to changes in cloudiness: Results from two North American deciduous forests, J. Geophys. Res., 104, 31421-31434, doi:10.1029/1999JD901068, 1999.

Gu, L., Baldocchi, D., Verma, S. B., Black, T. A., Vesala, T., Falge, E. M., and Dowty, P. R.: Advantages of diffuse radiation for terrestrial ecosystem productivity, J. Geophys. Res.-Atmos., 107, ACL 2-1-ACL 2-23, doi:10.1029/2001JD001242, 2002.

Gu, L., Baldocchi, D., Wofsy, S. C., Munger, J. W., Michalsky, J. J., Urbanski, S. P., and Boden, T. A.: Response of a deciduous forest to the Mount Pinatubo eruption: Enhanced photosynthesis, Science, 299, 2035-2038, doi:10.1126/science.1078366, 2003.

Heckendorn, P., Weisenstein, D., Fueglistaler, S., Luo, B. P., Rozanov, E., Schraner, M., Thomason, L. W., and Peter, T.: The impact of geoengineering aerosols on stratospheric temperature and ozone, Environ. Res. Lett., 4, 045108, doi:10.1088/17489326/4/4/045108, 2009.

Irvine, P. J., Ridgwell, A., and Lunt, D. J.: Assessing the regional disparities in geoengineering impacts, Geophys. Res. Lett., 37, L18702, doi:10.1029/2010GL044447, 2010.
Jenkinson, D. S., Adams, D. E., and Wild, A.: Model estimates of $\mathrm{CO}_{2}$ emissions from soil in response to global warming, Nature, 351, 304-306, doi:10.1038/351304a0, 1991.

Jones, A., Haywood, J., Boucher, O., Kravitz, B., and Robock, A.: Geoengineering by stratospheric $\mathrm{SO}_{2}$ injection: results from the Met Office HadGEM2 climate model and comparison with the Goddard Institute for Space Studies ModelE, Atmos. Chem. Phys., 10, 5999-6006, doi:10.5194/acp-10-5999-2010, 2010.

Jones, A., Haywood, J. M., Alterskjær, K., Boucher, O., Cole, J. N. S., Curry, C. L., Irvine, P. J., Ji, D., Kravitz, B., Kristjánsson, J. E., Moore, J. C., Niemeier, U., Robock, A., Schmidt, H., Singh, B., Tilmes, S., Watanabe, S., and Yoon, J-H.: The impact of abrupt suspension of solar radiation management (termination effect) in experiment G2 of the Geoengineering Model Intercomparison Project (GeoMIP), J. Geophys. Res.-Atmos., 118, 97439752, doi:10.1002/jgrd.50762, 2013.

Jones, C. D. and Cox, P. M.: Modeling the volcanic signal in the atmospheric $\mathrm{CO}_{2}$ record, Global Biogeochem. Cy., 15, 453-465, doi:10.1029/2000GB001281, 2001.

Kalidindi, S., Govindasamy, B., Angshuman, M., and Caldeira, K.: Modeling the solar radiation management: A comparison of simulations using reduced solar constant and stratospheric sulphate aerosols, Clim. Dynam., 44, 2909-2925, doi:10.1007/s00382014-2240-3, 2015.

Kanniah, K. D., Beringer, J., North, P., and Hutley, L.: Control of atmospheric particles on diffuse radiation and terrestrial plant productivity: A review, Prog. Phys. Geogr., 36, 209-237, doi:10.1177/0309133311434244, 2012.

Keeling, C. D., Whorf, T. P., Wahlen, M., and van der Plichtt, J.: Interannual extremes in the rate of rise of atmospheric carbon dioxide since 1980, Nature, 375, 666-670, doi:10.1038/375666a0, 1995.

Knohl A. and Baldocchi, D. D.: Effects of diffuse radiation on canopy gas exchange processes in a forest ecosystem, J. Geophys. Res., 113, G02023, doi:10.1029/2007JG000663, 2008.

Kravitz, B., Robock, A., Boucher, O., Schmidt, H., Taylor, K., Stenchikov, G., and Schulz, M.: The Geoengineering Model Intercomparison Project (GeoMIP), Atmos. Sci. Lett., 12, 162 167, doi:10.1002/as1.316, 2011.

Kravitz, B., MacMartin, D. G., Robock, A., Rasch, P. J., Ricke, K. L., Cole, J. N. S., Curry, C. L., Irvine, P. J., Ji, D., Keith, D. W., Kristjánsson, J. E., Moore, J. C., Muri, H., Bingh, B., Tilmes, S., Watanabe, S., Yang, S., and Yoon, J.-H.: A multi-model assessment of regional climate disparities caused by solar geoengineering, Environ. Res. Lett., 9, 074013, doi:10.1088/17489326/9/7/074013, 2014.

Lamarque, J.-F., Emmons, L. K., Hess, P. G., Kinnison, D. E., Tilmes, S., Vitt, F., Heald, C. L., Holland, E. A., Lauritzen, P. H., Neu, J., Orlando, J. J., Rasch, P. J., and Tyndall, G. K.: CAM-chem: description and evaluation of interactive atmospheric chemistry in the Community Earth System Model, Geosci. Model Dev., 5, 369-411, doi:10.5194/gmd-5-369-2012, 2012.

Lawrence, D. M., Olesen, K. W., Flanner, M. G., Fletcher, C. G., Lawrence, P. J., Levis, S., Swenson, S. C., and Bonan, G. B.: The CCSM4 Land Simulation, 1850-2005: Assessment of surface climate and new capabilities, J. Climate, 25, 2240-2260, doi:10.1175/JCLI-D-11-00103.1, 2012. 
Leakey, A. D. B., Ainsworth, E. A., Bernacchi, C. J., Rogers, A., Long, S. P., and Ort, D. R.: Elevated $\mathrm{CO}_{2}$ effects on plant carbon, nitrogen, and water relations: Six important lessons from FACE, J. Exp. Bot., 60, 2859-2876, doi:10.1093/jxb/erp096, 2009.

Lucht, W., Pretice, I. C., Myneni, R. B., Sitch, S., Friedlingstein, P., Cramer, W., Bousquet, P., Buermann, W., and Smith, B.: Climatic control of the high-latitude vegetation greening trend and Pinatubo effect, Science, 296, 1687-1689, doi:10.1126/science.1071828, 2002.

Misson, L., Lunden, M., McKay, M., and Goldstein, A. H.: Atmospheric aerosol light scattering and surface wetness influence the diurnal pattern of net ecosystem exchange in a semi-arid ponderosa pine plantation, Agr. Forest Meteorol., 129, 69-83, doi:10.1016/j.agrformet.2004.11.008, 2005.

Meinshausen, M., Smith, S. J., Calvin, K., Daniel, J. S., Kainuma, M. L. T., Lamarque, J.-F., Matsumoto, K., Montzka, S. A., Raper, S. C. B., Riahi, K., Thomason, A., Velders, G. J. M., and van Vuuren, D. P. P.: The RCP greenhouse gas concentrations and their extension from 1765 to 2300, Climatic Change, 109, 213241, doi:10.1007/s10584-011-0156-z, 2011.

Mercado, L. M., Bellouin, N., Sitch, S., Boucher, O., Huntingford, C., Wild, M., and Cox, P. M.: Impact of changes in diffuse radiation on the global land carbon sink, Nature, 458, 1014-1017, doi:10.1038/nature07949, 2009.

Neely III, R. R., Conley, A., Vitt, F., and Lamarque, J. F.: A consistent prescription of stratospheric aerosol for both radiation and chemistry in the Community Earth System Model (CESM1), Geosci. Model Dev. Discuss., 8, 10711-10734, doi:10.5194/gmdd-8-10711-2015, 2015.

Nemani, R. R., Keeling, C. D., Hashimoto, H., Jolly, W. M., Piper, S. C., Tucker, C. J., Myneni, R. B., and Running, S. W.: Climate-driven increases in global terrestrial net primary production from 1982 to 1999 , Science, 300, 1560-1563, doi:10.1126/science.1082750, 2003.

Niemeier, U., Schmidt, H., and Timmreck, C.: The dependency of geoengineered sulfate aerosol on the emission strategy, Atmos. Sci. Lett., 12, 189-194, doi:10.1002/asl.304, 2011.

Niemeier, U., Schmidt, H., Alterskjær, K., and Kristjánsson, J. E.: Solar irradiance reduction via climate engineering: Impact of different techniques on the energy balance and the hydrological cycle, J. Geophys. Res.-Atmos., 118, 11905-11917, doi:10.1002/2013JD020445, 2013.

Niyogi, D., Chang, H.-I., Saxena, V. K., Holt, T., Alapaty, K., Booker, F., Chen, F., Davis, K. J., Holben, B., Matsui, T., Meyers, T., Oechel, W. C., Pielke Sr., R. A., Wells, R., Wilson, K., and Xue, Y.: Direct observations of the effect of aerosol loading on net ecosystem $\mathrm{CO}_{2}$ exchanges over different landscapes, Geophys. Res. Lett., 31, L20506, doi:10.1029/2004GL020915, 2004.

Nowack, P. J., Abraham, N. L., Braesicke, P., and Pyle, J. A.: Ozone changes under solar geoengineering: implications for UV exposure and air quality, Atmos. Chem. Phys. Discuss., 15, 3197332004, doi:10.5194/acpd-15-31973-2015, 2015.

Oliveira, P. H. F., Artaxo, P., Pires, C., Lucca, S. D., Procopio, A., Holben, B., Schafer, J., Cardoso, L. F., Wofsy, S. C., and Rocha, H. R.: The effects of biomass burning aerosols and clouds on the $\mathrm{CO}_{2}$ flux in Amazonia, Tellus B, 59, 338-349, doi:10.1111/j.1600-0889.2007.00270.x, 2007.
Pan, Y., Birdsey, R. A., Fang, J., Houghton, R., Kauppi, P. E., Kurz, W. A., Phillips, O. L., Shvidenko, A., Lewis, S. L., Canadell, J. G., Ciais, P., Jackson, R. B., Pacala, S. W., McGuire, A. D., Piao, S., Rautiainen, A., Sitch, S., and Hayes, D.: A large and persistent carbon sink in the world's forest, Science, 333, 988993, doi:10.1126/science.1201609, 2011.

Phillips, O. L., Aragão, L. E. O. C., Lewis, S. L., Fisher, J. B., Lloyd, J., López-González, G., Malhi, Y., Monteagudo, A., Peacock, J., Quesada, C. A., van der Heijden, G., Almeida, S., Amaral, I., Arroyo, L., Aymard, G., Baker, T. R., Bánki, O., Blanc, L., Bonal, D., Brando, P., Chave, J., de Oliveira, Á. C. A., Cardozo, N. D., Czimczik, C. I., Feldpausch, T. R., Freitas, M. A., Gloor, E., Higuchi, N., Jiménez, E., Lloyd, G., Meir, P., Mendoza, C., Morel, A., Neill, D. A., Nepstad, D., Patiño, S., Peñuela, M. C., Prieto, A., Ramírez, F., Schwarz, M., Silva, J., Silveira, M., Thomas, A. S., ter Steege, H., Stropp, J., Vásquez, R., Zelazowski, P., Álvarez Dávila, E., Andelman, S., Andrade, A., Chao, K-J., Erwin, T., Di Fiore, A., Honorio C., E., Keeling, H., Killeen, T. J., Laurance, W. F., Peña Cruz, A., Pitman, N. C. A., Núñez Vargas, P., Ramírez-Angulo, H., Rudas, A., Salamão, R., Silva, N., Terborgh, J., and Torres-Lezama, A.: Drought sensitivity to the Amazon rainforest, Science, 323, 1344-1347, doi:10.1126/science.1164033, 2009.

Pitari, G., Aquila, V., Kravitz, B., Robock, A., Watanabe, S., Cionni, I., De Luca, N., Di Genova, G., Mancini, E., and Tilmes, S.: Stratospheric ozone response to sulfate geoengineering: Results from the Geoengineering Model Intercomparison Project (GeoMIP), J. Geophys. Res.-Atmos., 119, 2629-2653, doi:10.1002/2013JD020566, 2014.

Pongratz, J., Lobell, D. B., Cao, L., and Caldeira, K.: Crop yields in a geoengineered climate, Nature Clim. Change, 2, 101-105, doi:10.1038/nclimate1373, 2012.

Rap, A., Spracklen, D. V., Mercado, L., Reddington, C. L., Haywood, J. M., Ellis, R. J., Phillips, O. L., Artaxo, P., Bonal, D., Coupe, N. R., and Butt, N.: Fires increase Amazon forest productivity through increases in diffuse radiation, Geophys. Res. Lett., 42, 4654-4662, doi:10.1002/2015GL063719, 2015.

Rasch, P. J., Crutzen, P. J., and Coleman, D. B.: Exploring the geoengineering of climate using stratospheric sulfate aerosols: the role of particle size, Geophys. Res. Lett., 35, L02809, doi:10.1029/2007GL032179, 2008a.

Rasch, P. J., Tilmes, S., Turco, R. P., Robock, A., Oman, L., Chen, C.-C. (Jack), Stenchikov, G. L., and Garcia, R. R.: An overview of geoengineering of climate using stratospheric sulfate aerosols, Philos. T. R. Soc. A., 366, 4007-4037, doi:10.1098/rsta.2008.0131, 2008b.

Reddy, V. R., Reddy, K. R., and Hodges, H. F.: Carbon dioxide enrichment and temperature effects on cotton canopy photosynthesis, transpiration, and water-use efficiency, Field Crop. Res., 41, 13-23, doi:10.1016/0378-4290(94)00104-K, 1995.

Robock, A.: Volcanic eruptions and climate, Rev. Geophys., 38, 191-219, 2000.

Robock, A.: Cooling following large volcanic eruptions corrected for the effect of diffuse radiation on tree rings, Geophys. Res. Lett., 32, L06702, doi:10.1029/2004GL022116, 2005.

Robock, A.: 20 reasons why geoengineering may be a bad idea, B. Atomic Sci., 64, 14-18, doi:10.2968/064002006, 2008.

Robock, A.: Will geoengineering with solar radiation management ever be used?, Ethics, Policy \& Environment, 15, 202-205, 2012. 
Robock, A.: Stratospheric aerosol geoengineering, Environ. Sci. Technol., 38, 162-185, 2014.

Robock, A., Oman, L., and Stenchikov, G.: Regional climate responses to geoengineering with tropical and Arctic $\mathrm{SO}_{2}$ injections, J. Geophys. Res., 113, D16101, doi:10.1029/2008JD010050, 2008.

Robock, A., Marquardt, A. B., Kravitz, B., and Stenchikov, G.: The benefits, risks, and costs of stratospheric geoengineering, Geophys. Res. Lett., 36, L19703, doi:10.1029/2009GL039209, 2009.

Roderick, M., Farquhar, G. D., Berry, S. L., and Noble, I. R.: On the direct effect of clouds and atmospheric particles on the productivity and structure of vegetation, Oecologia, 129, 21-30, 2001.

Sage, R. F. and Kubien, D. S.: The temperature response of C3 and C4 photosynthesis, Plant Cell Environ., 30, 1086-1106, doi:10.1111/j.1365-3040.2007.01682.x, 2007.

Tilmes, S., Müller, R., and Salawitch, R.: The sensitivity of polar ozone depletion to proposed geoengineering schemes, Science, 320, 1201-1204, doi:10.1126/science.1153966, 2008.

Tilmes, S., Fasullo, J., Lamarque, J.-F., Marsh, D. R., Mills, M., Alterskjær, K., Muri, H., Kristjánsson, J. E., Boucher, O., Schulz, M., Cole, J. N. S., Curry, C. L., Jones, A., Haywood, J., Irvine, P. J., Ji, D., Moore, J. C., Karam, D. B., Kravtiz, B., Rasch, P. J., Singh, B., Yoon, J-H., Niemeier, U., Schmidt, H., Robock, A., Yang, S., and Watanabe, S.: The hydrological impact of geoengineering in the Geoengineering Model Intercomparison Project (GeoMIP), J. Geophys. Res.-Atmos., 118, 11036-11058, doi:10.1002/jgrd.50868, 2013.

Tilmes, S., Lamarque, J.-F., Emmons, L. K., Kinnison, D. E., Ma, P.-L., Liu, X., Ghan, S., Bardeen, C., Arnold, S., Deeter, M., Vitt, F., Ryerson, T., Elkins, J. W., Moore, F., Spackman, J. R., and Val Martin, M.: Description and evaluation of tropospheric chemistry and aerosols in the Community Earth System Model (CESM1.2), Geosci. Model Dev., 8, 1395-1426, doi:10.5194/gmd-8-13952015, 2015a.
Tilmes, S., Mills, M. J., Niemeier, U., Schmidt, H., Robock, A., Kravitz, B., Lamarque, J.-F., Pitari, G., and English, J. M.: A new Geoengineering Model Intercomparison Project (GeoMIP) experiment designed for climate and chemistry models, Geosci. Model Dev., 8, 43-49, doi:10.5194/gmd-8-43-2015, 2015 b.

Tilmes, S., Lamarque, J.-F., Emmons, L. K., Kinnison, D. E., Marsh, D., Garcia, R. R., Smith, A. K., Neely, R. R., Conley, A., Vitt, F., Val Martin, M., Tanimoto, H., Simpson, I., Blake, D. R., and Blake, N.: Representation of the Community Earth System Model (CESM1) CAM4-chem within the ChemistryClimateModel Initiative (CCMI), Geosci. Model Dev. Discuss., doi:10.5194/gmd-2015-237, in review, 2016.

Tjiputra, J. F., Grini, A., and Lee, H.: Impact of idealized future stratospheric aerosol injection on the large scale ocean and land carbon cycles, J. Geophys. Res.-Biogeo., 120, doi:10.1002/2015JG003045, online first, 2015.

Vitousek, P. M. and Howarth, R. W.: Nitrogen limitation on land and in the sea: How can it occur?, Biogeochemistry, 13, 87-115, 1991.

Wigley, T. M. L.: A combined mitigation/geoengineering approach to climate stabilization, Science, 314, 452-454, doi:10.1126/science.1131728, 2006.

Wild, M.: Global dimming and brightening: A review, J. Geophys. Res.-Atmos., 114, D00D16, doi:10.1029/2008JD011470, 2009.

Xia, L., Robock, A., Cole, J., Curry, C. L., Ji, D., Jones, A., Kravitz, B., Moore, J. C., Muri, H., Niemeier, U., Singh, B., Tilmes, S., Watanabe, S., and Yoon, J.-H.: Solar radiation management impacts on agriculture in China: A case study in the Geoengineering Model Intercomparison Project (GeoMIP), J. Geophys. Res.Atmos., 119, 8695-8711, doi:10.1002/2013JD020630, 2014. 